Research Article

\title{
Vegetative structure and zonal distribution of true mangroves in Shwe-Thaung-Yan coastal areas, Myanmar
}

\begin{abstract}
The survey was conducted in the mangrove forests around the Magyi and Utto Creeks at Shwe-Thaung-Yan coastal areas in Ayeyarwady Delta region, April 2018. Transect lines were laid as lower, middle and upper, and quadrate plots based on Point Center Quarter Method (PCQM) P-DATA PRO were used. A total of 15 species of true mangrove was recorded. Rhizophora apiculata and Bruguiera gymnorhiza are the most dominant and distributed species in the study area. Followed by Bruguiera sexangulata, Cerop tagal and Rhizophora mucronata then remaining species. Zonation pattern of mangroves species as lower, middle, upper was also examined in study areas. Among than 1 species in Near Threaten (NT), 1 species in Critically Endangered (CR), 1 species in Endangered (EN) and remaining species are Least Concern (LC) had been considered according with IUCN red list. The environmental parameters such as water salinity and temperature, soil salinity, soil temperature and soil $\mathrm{pH}$ of study area were also recorded.
\end{abstract}

Keyword: ayeyarwady region, environmental parameters, lowers, magyi and utto creek, middle, mangrove forest, shwe-thaung-yan coastal, transect lines, upper, zonal pattern
Volume 10 Issue I - 202I

\author{
Soe-Win,' Tin-Zar-Ni-Win ${ }^{2}$ \\ 'Department of Marine Science, Mawlamyine University, \\ Myanmar \\ 2Marine Biologist, Fauna \& Flora International (FFI), Myanmar \\ Correspondence: Soe-Win, Marine Science, Mawlamyine \\ University, Myanmar, Email soewinmarin@gmail.com
}

Received: January 29, 2021 | Published: February 26, 2021

\section{Introduction}

Myanmar has along coastline which is $2832 \mathrm{~km}$ and can be divided into three coastal areas. The Rakhine Coastal Region (from the mouth of Naaf River to Maw Tin Point, about 740km length), the Ayeyarwady Delta and the Gulf of Mottama Coastal Region (Maw Tin Point to the Gulf of Mottama, about 460km in length) and Tanninthayi Coastal Region (from the Gulf of Mottama to the mouth of Pakchan River, about $1200 \mathrm{~km}$ length), extending along the Bay of Bengal and Andaman Sea. There are estuaries with deltaic systems, and numerous offshore islands along with a considerable diversity of coastal habitats, including mangroves, seagrass meadows, Coral reefs, sandy beaches and mudflats along the three Coastal Regions of Myanmar.

Myanmar has the fourth largest expense of mangrove area in Southeast Asia after Malaysia, Bangladesh and Papua New Guinea. Myanmar possesses $4 \%$ of world mangroves, and $8.8 \%$ of Southeast Asia mangroves. In these mangroves, $46 \%$ are including in Ayeyarwady, $37 \%$ in Taninthayi and $17 \%$ in Rakhine. So mangrove forest area greatest in Ayeyarwady Delta.

Mangroves of Shwe-Thaung-Yan coastal zone dominant along the deltaic areas of the Magyi and Utto tidal creeks. The distance of Magyi tidal creek and Utto creek has nine miles and seven miles respectively. Today, mangrove forests in Shwe-Thaung-Yan coastal areas are being degraded and destroyed on a larger scale through the natural disturbance and anthropogenic activities such as transforming to agriculture land, aquaculture ponds, salt pond/land etc, which are major causes of their degradation land loss of mangrove ecosystem.

The objective of this study is to know vegetative structure and zonal distribution of true mangrove species in Shwe-Thaung-Yan coastal areas.

\section{Material and methods}

The present study was conducted in the mangrove forest around Magyi tidal creek (Lat12.34 15'72" N, Long 94.29 46'27'E) in April 2018(Figure 1). A total of six random transects were set up based on the different forest conditions such as upper, middle, lower at Magyi and
Utto tidal creeks, Shwe-Thaung-Yan coastal areas. The transect lines were measured by using diameter tape in meter. The distances and intervals of each transect were shown in Table 1.Totally, 15 sampling plots were set up in each transect. The measurement of plot is $10 \mathrm{~m}^{2}$, respectively. Each plot subdivided into four quadrants. Only one of nearest tree was recorded in each quadrant. The data of vegetation was recorded by using Point Center Quarter Method (PCQM) according to Dahdouh-Guebas, $\mathrm{F}$ and Koedan. ${ }^{1}$ Then, the variable parameters such as the stem density (De), basal area $(\mathrm{Ba})$ for each species and for entire mangrove stand, the complexity index (C.I), the relative density $\left(D_{r}\right)$, the relative dominance $\left(D_{r}\right)$, the relative frequency $\left(F_{r}\right)$ and the importance value (I.V) for each species were calculated by using Microsoft Excel-base Workbook P-DATA-PRO_1000 (Version 5.01) software. For all recorded mangrove species: flower, fruit, bud, leave, root and stem were recorded by using digital camera. The location of study areas were marked by using GPS for each transects line in the study areas. The environmental parameters such as soil temperature, soil salinity, water salinity, and water temperature and soil $\mathrm{pH}$ were measured at the field immediately. (Figure 2-5).

\section{Results and discussion}

In the present study area, a total of 15 species belong to 9 genera from 7 families of true woody mangrove plants in the Magyi and Utto tidal creeks, Shwe-Thaung-Yan coastal areas were recorded .They are 7 species from family Rhizophoraceae, 3 species in family Avicenniaceae, one species were recorded in families Sonneratiaceae, Meliaceae and Steruliaceae, Arecaceae and Combretaceae at Magyi and Utto creeks, Shwe-Thaung-Yan coastal areas. The Systematic positions of classification of recorded species were described in Table 2.

The mangrove ecosystem in the tropical regions, along coastal shorelines and associated is important for many flora and fauna. The present study was conducted at two stations which represented different mangrove types in upper, middle and lower zones. The present study deals with the occurrence, composition and vegetative structure of true mangrove in Magyi and Utto Creeks, Shwe-ThaungYan coastal area. 


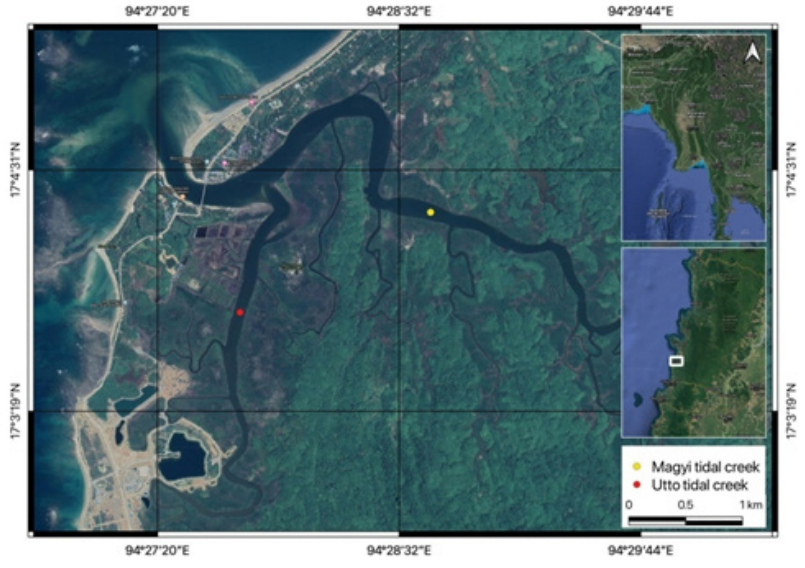

Figure I Map showing the location of study area: Magyi and Utto tidal creek, Shwe-Thaung-Yan Area.

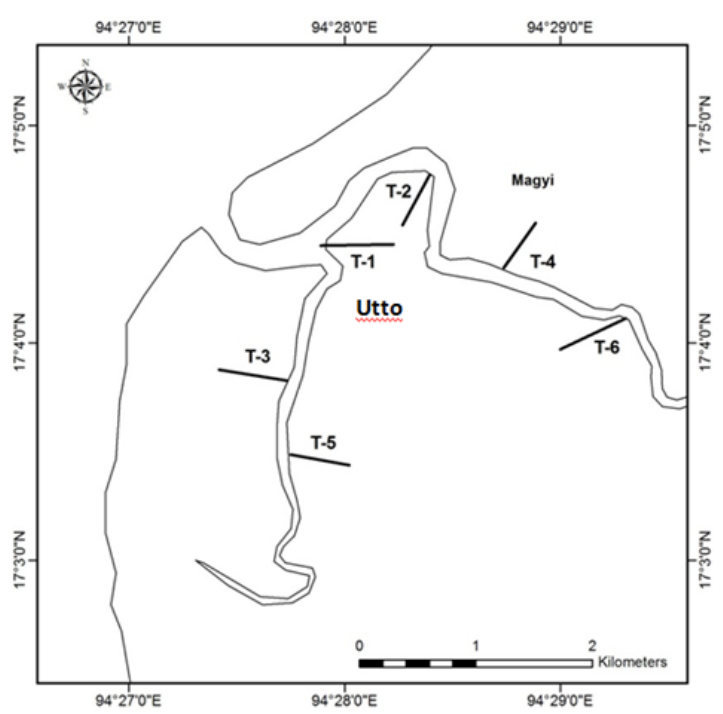

Figure 2 The location, distance of transects, and plot interval of each transect around the Magyi and Utto tidal creeks mangrove, Shwe-Thaung-Yan coastal Area.

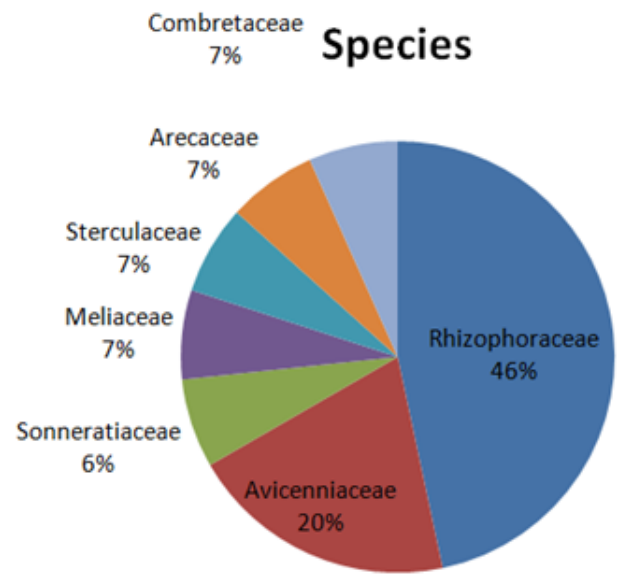

Figure 3 Species composition of mangrove in the Magyi and Utto creek,ShweThaung-Yan coastal areas.

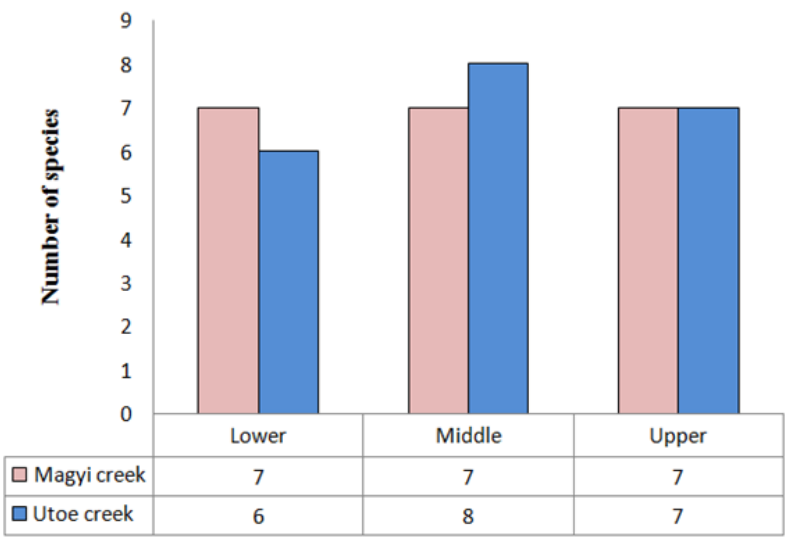

Figure 4 Zonal distribution of number of mangroves species in the study sites.

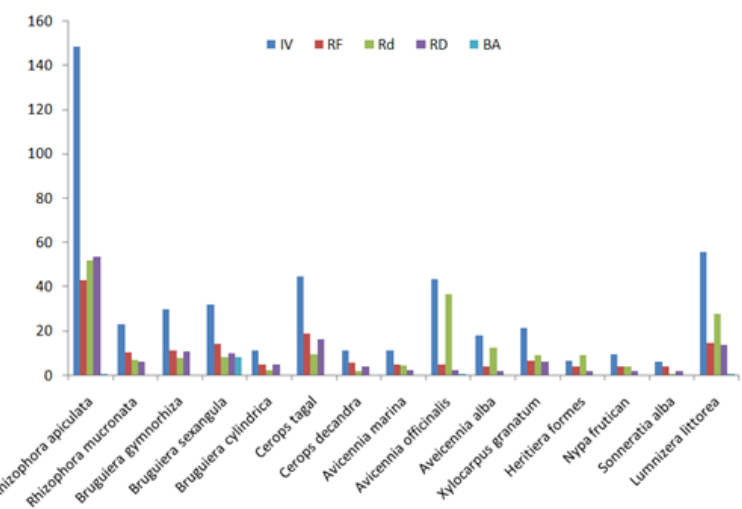

Figure 5 Forest parameter of different mangrove species at study sites. IV, Important Value; RF, Relative Dominance; Rd, Relative dominance; RD, Relative Density; BA, Basal Area.

There are many previous studies in Myeik and Ayeyarwady delta Area. Among them, a total of about 50 species of mangrove, ${ }^{2}$ the zonation of true and associate mangrove species distribution, ${ }^{3}$ botanical study of importance of mangrove ecosystem for conservation and Management purpose, ${ }^{4} 44$ species of mangrove including true and associate species of mangroves ${ }^{5}$ and 30 species including true mangrove and mangrove associates ${ }^{6}$ were recorded in Myeik Coastal area. Moreover, the zonation pattern of mangrove in Magyi Tidal Creek by using transect lines method $^{7}$, species composition and zonation pattern of mangrove of kandon-kani, Amherst and Setse areas, ${ }^{8}$ the mangrove reforestation from the Ayeyarwady Delta. ${ }^{9}$ The species composition, zonation and succession of mangrove community along the Magyi coastal area. ${ }^{10}$

In some cases, zonation may be very irregular or restricted to a particular part of the tidal gradient. ${ }^{11}$ Similarly, the zone of study sites termed as upper, middle and lower zone. A total of 15 species of true mangrove were observed in the .present study in Shwe-Thaung-Yan coastal area were distributed, Transet 1,3 and 5 were measured at Magyi creek and Transects 2,4 and 6 were measured at Utto tidal creek. According to the zonal species distribution, the same zonal species distribution in Magyi, but the highest species were found in middle and lowest species in lower zone in Utto tidal creek. Two species of Bruguiera mucronata and Rhizophora apiculata were distributed all the study sites. And then followed Bruguiera sexangular,Cerop tagal and Rhizophora mucronata were zonal distributed. Avicennia 
alba, Cerops dencandra,Lumnizera littorea, Sonneratia alba and Xylocarpus granatum were upper zonal distributed while ,Bruguiera cylindrical, Cerops dencandra,Nypa frutican,Heritiera forms and
Xylocarpus granatum were also lower zonal distribution and then Avicennia alba, A.marina, A.officinalis were distributed only at the middle zone.

Table I The location, distance of transect, and plot interval of each transect around the Magyi and Utto tidal creek mangroves, Shwe-Thaung-Yan coastal Area

\begin{tabular}{|c|c|c|c|c|c|}
\hline Sr. No. & Transect & Latitude & Longitude & Distance (m) & Plot Interval (m) \\
\hline I & $T-I$ & $17^{\circ} 32^{\prime} 83^{\prime \prime} \mathrm{N}$ & $94^{\circ} 27^{\prime} 5$ I" E & 450 & 30 \\
\hline 2 & $\mathrm{~T}-2$ & $17^{\circ} 42^{\prime} 75^{\prime \prime} \mathrm{N}$ & $94^{\circ} 29^{\prime} 9 I^{\prime \prime} \mathrm{E}$ & 450 & 30 \\
\hline 3 & $\mathrm{~T}-3$ & $17^{\circ} 42^{\prime} 69^{\prime \prime} \mathrm{N}$ & $94^{\circ} 28^{\prime} 2 I^{\prime \prime} \mathrm{E}$ & 450 & 30 \\
\hline 4 & $\mathrm{~T}-4$ & $17^{\circ} 40^{\prime} 26^{\prime \prime} \mathrm{N}$ & $94^{\circ} 28^{\prime} 46^{\prime \prime} \mathrm{E}$ & 450 & 30 \\
\hline 5 & $\mathrm{~T}-5$ & $17^{\circ} 35^{\prime} 16^{\prime \prime} \mathrm{N}$ & $94^{\circ} 27^{\prime} 33^{\prime \prime} \mathrm{E}$ & 450 & 30 \\
\hline 6 & $T-6$ & $17^{\circ} 43^{\prime} 8 I^{\prime \prime} \mathrm{N}$ & $94^{\circ} 28^{\prime} 19^{\prime \prime} \mathrm{E}$ & 450 & 30 \\
\hline
\end{tabular}

Table 2 Classification list of true mangrove species in Magyi and Utto tidal creeks, Shwe-Thaung-Yan coastal areas

\begin{tabular}{lllll}
\hline Family & Genus & Sr. No. & Species & IUCN Read List \\
\hline & Rhizophora & 1 & Rhizophora apiculata & LC \\
& & 2 & Rhizophora mucronata & LC \\
I.Rhizophoraceae & 3 & Bruguiera gymnorhiza & LC \\
& Bruguiera & 4 & Bruguiera sexangula & LC \\
& & 5 & Bruguiera cylindrical & LC \\
& Ceriops & 6 & Ceriops decandra & NT \\
2.Avicenniaceae & & 7 & Ceriops tagal & LC \\
& & 8 & Avicennia alba & LC \\
3.Sonneratiaceae & Avicennia & 9 & Avicennia marina & LC \\
4.Meliaceae & & 10 & Avicennia officinalis & LC \\
5.Sterculiaceae & Xylocarpus & 12 & Sonneratia alba & CR \\
6.Arecaceae & Heritiera & 13 & Heritiera formes & LC \\
7.Combretaceae & Nypa & 14 & Nypa fruticans & EN \\
& Lumnizera & 15 & Lumnizera littorea & LC \\
\hline
\end{tabular}

Abbreviations: LC, least concern; NT, near threatened;VU, vulnerable; EN, endangered; CR, critically endangered

The structure and composition, called mangrove vegetation structure dynamics, are rarely studied worldwide. The result of present study recognized the various types of dynamics. As the calculated result, mean basal area was variable ranging from (0.01 to 0.6), mean relative density was variable ranging from( 1.7 to 53.5$)$, mean relative dominance was variable ranging from( 0.5 to 51.6$)$, mean relative frequency was variable ranging from(3.7 to 42.9) and then mean important value was variable ranging from(6.1 to 148.12 ) at study sites.

The high importance value in the Magyi forest of Phizophora apiculata indicates that the forest is ecologically dominated. From the calculation, mean high of tree was 2.2-2.5 at Utto while 1.9-2.6 at Magyi tidal creek, therefore the trees at Magyi were higher than Utto creek. The total forest densities for trees were 0.24-0.35at Utto while 0.21-0.34 at Magyi creek tree par meter square. Regular distribution was rarely found; this is probably due to intraspecific competition at a local scale. However, Fangliang et al., 1997 mentioned that there is a negative correlation between per capital death rate and population density. Kairo et al., $2002^{12}$ also showed that the sapling density varied greatly between localities but was on average very high, which implies adequate recruitment inmost localities. The circumference of this species is large as well as the height is low. Basal area is related to the circumference of trees. At Utto, the number of complexity index (mean) was highest (2.5-7.7) while (3.7-5.8) at Magyi. The mean number of multiple stem tree were2-2.3 at Utto creek while 2.3 at Magyi. In the present study, total frequency range of Magyi was $140-180 \%$ while Utoe was $140-173.3 \%$. Total basal area range of Utto $0.743-1.4566 \mathrm{~m}^{2} / 0.1$ ha while Magyi was $1.049-1.492 \mathrm{~m}^{2} / 0.1$ ha because Rhizophoea apiculata is more prevalent in Magyi. According to the results, Phizophora apiculatas howed the highest mean basal area, mean relative density, mean relative dominance, mean relative frequency and mean importance value of forest parameters at all stations while Heritiera forms and Sonneratia alba were lowest. At the Magyi and Utto, the species of , Phizophora apiculata in T-1,T2,T-3,T-4 and T-5 were the most abundance species but Bruguiera sexangular and Bruguiera gymnorhiza in T-1, Bruguiera cylindrical T-2, Cerop dencandra T-5 and Sonneratia alba T-4 were least abundance species in the transect according to their rank (Rank-7).

Regarding the environmental parameter measurements, water salinity $(35.8 \%$ ), highest at T-6, followed by $(35.2 \%)$ at T-4,(35\%) at T-1and T-5, (32\%) at T-2 and T-3. Transect 6 is the highest water salinity while transect 2 and 3 are lowest. Soil salinity was highest 
$55 \%$ at transect 1 while lowest $30 \%$ at Transect 2 . The value of soil $\mathrm{pH}$ was highest 6.4 in transect 5, followed by 6.2 in Transects 1 and 6, 6.0 in Transect4 , 5.9 in Transect 3 and then5.8 in transect 2 in studying the period at Magyi.

Mangroves and adjacent mudflats are found in all coastal provinces and are widely distributed across the entire coastline. Cunha-Lignon et al pointed regarding individual mangrove species rarely occupy entire estuaries from sea mouth to the tidal limit upstream. Also, Duke ${ }^{13}$ mentioned that each of the mangrove species has a preferred up river estuarine location based on its salinity tolerance range. Likewise, the present study revealed that the various salinity ranges controlled significantly upon the distribution of species of mangroves growing in the study sites from the mouth to the head of the Magyi creek.

Regarding the soil type, Malar ${ }^{3}$ demonstrated that Avicennia alba, Sonneratia alba, and Rhizophora mucronata plants could grow well on all substrate conditions such as muddy, very soft muddy and sandy mud area. This implies that the substrate types have no restrictions on their distribution along the Magyi tidal creek. The present study showed the same conditions similar with her results on the distribution of mangroves. In addition, the outcomes of this study displayed similar to that of Nan Htwe Htwe Maung ${ }^{7}$ who studied the distribution of mangrove species subjected to varying conditions of salinity concentrations, nutrient levels, substrate structures and tidal movement in Magyi tidal creek.
Mangrove seedlings are apparently adapted to shaded undestroyed environment while mature trees respond better in the sunlight canopy ${ }^{4}$ but shade tolerance differ among mangrove species. ${ }^{15}$ The mean high trees variable ranging (from 1.9 to $2.6 \mathrm{~m}$ ), total forest density variable ranging (from 210.7 to 349.7 ), and Complexity index variable ranging (from 2.5 to 7.7 ).

The present study has been carried out in the Magyi and Utto creeks, Shwe-Thaung- Yan coastal Area. The method used in the present study the first attempt in Myanmar. The study site was selected and measured the vegetative structure and recorded the species composition so as to estimate the forest value. Almost all of the forests in Utto and Magyi creeks showed not good condition because of several human impacts and activities. Today, mangrove forests are being degraded and destroyed on a larger scale globally through the natural disturbance and anthropogenic activities such as transforming to agriculture land, aquaculture ponds, etc., which are major causes of their degradation and loss of mangroves ecosystem. However, this station may be recovered in the next few years because many juveniles of mangrove species were influent seriously. There should be emphasis on the implementation of reforestation and raising awareness and knowledge of local people on the value of mangrove community in those stations (Table 3-7)

Table 3 Zonal distribution of number of mangroves species in the study sites

\begin{tabular}{|c|c|c|c|c|c|c|c|}
\hline \multirow{3}{*}{$\begin{array}{l}\text { Sr. } \\
\text { No. }\end{array}$} & \multirow{3}{*}{ Species } & \multicolumn{6}{|c|}{ Zonation } \\
\hline & & \multicolumn{2}{|c|}{ Lower } & \multicolumn{2}{|c|}{ Middle } & \multicolumn{2}{|c|}{ Upper } \\
\hline & & T-I & $\mathrm{T}-2$ & T- 3 & $\mathrm{~T}-4$ & T-5 & T-6 \\
\hline 1 & Rhizophora apiculata & + & + & + & + & + & + \\
\hline 2 & Rhizophora mucronata & - & - & + & + & + & + \\
\hline 3 & Bruguiera gymnorhiza & + & + & + & + & + & + \\
\hline 4 & Bruguiera sexangular & + & + & + & + & - & + \\
\hline 5 & Bruguiera clyindrica & - & + & + & - & - & - \\
\hline \multicolumn{2}{|c|}{ Ceriops decandra } & + & - & - & + & - & \\
\hline 7 & Ceriops tagal & - & + & + & + & + & + \\
\hline 8 & Avicennia alba & - & - & - & + & - & + \\
\hline 9 & Avicennia officinalis & - & - & + & - & - & - \\
\hline 10 & Avicennia marina & - & - & + & - & - & - \\
\hline 11 & Sonneratia alba & - & - & - & + & - & + \\
\hline 12 & Xylocarpus granatum & + & + & - & - & + & - \\
\hline 13 & Heritiera formes & + & - & - & - & - & - \\
\hline 14 & Nypa fruticans & + & - & - & - & - & - \\
\hline 15 & Lumnizera littorea & - & - & - & - & + & - \\
\hline Total & & 6 & 7 & 8 & 7 & 7 & 7 \\
\hline
\end{tabular}

Table 4 Total forest or vegetation assemblage in Magyi mangrove, Shwe-Thaung-Yan coastal areas

\begin{tabular}{llllllll}
\hline Summary of PCQM based forestry parameters & \multicolumn{3}{c}{} & \multicolumn{3}{c}{ Uper } \\
& Lower & & Middle & \multicolumn{3}{c}{ Upper } \\
& T-1 & T-2 & T-3 & T-4 & T-5 & T-6 \\
\hline I Number of PCQM sample points & 15 & 15 & 15 & 15 & 15 & 15 \\
\hline
\end{tabular}


Table continued...

\begin{tabular}{|c|c|c|c|c|c|c|c|}
\hline \multicolumn{8}{|c|}{ Summary of PCQM based forestry parameters } \\
\hline & & \multicolumn{2}{|l|}{ Lower } & \multicolumn{2}{|c|}{ Middle } & \multicolumn{2}{|l|}{ Upper } \\
\hline & & T-I & $\mathrm{T}-2$ & T-3 & T-4 & T-5 & T-6 \\
\hline 2 & Total number of quadrants & 60 & 60 & 60 & 60 & 60 & 60 \\
\hline 3 & Number of empty quadrants & 2 & 24 & 4 & 18 & 11 & 7 \\
\hline 4 & Number of tree species & 6 & 6 & 7 & 7 & 8 & 7 \\
\hline 5 & Proportion of multiple- stemmed trees (\%) & 9 & 8 & 11 & 5 & 6 & 17 \\
\hline 6 & Mean number of stems in multiple stemmed & 2.2 & 2.3 & 2 & 2.3 & 2.3 & 2.3 \\
\hline 7 & Mean height $(m)$ & 2.3 & 1.9 & 2.2 & 2.1 & 2.5 & 2.6 \\
\hline 8 & Total forest density (trees $/ \mathrm{m}^{2}$ ) & 0.24 & 0.31 & 0.35 & 0.34 & 0.27 & 0.21 \\
\hline 9 & Total forest density (trees/0.I ha) & 224.1 & 310.3 & 349.7 & 340.9 & 269.4 & 210.7 \\
\hline 10 & Total basal area $\left(\mathrm{m}^{2} / 0 . \mathrm{lha}\right)$ & 0.7439 & 1.049 & 1.132 & 1.095 & 1.4566 & 1.492 \\
\hline II & Total frequency (c/o) & 173.3 & 140 & 166.7 & 180 & 140 & 180 \\
\hline 12 & Complexity Index (using mean height) & 2.5 & 3.7 & 6.2 & 5.4 & 7.7 & 5.8 \\
\hline
\end{tabular}

Table 5 Distribution of different mangrove species along the transects of Mgyi and Utto creek, Shwe-Thaung-Yan coastal area

\begin{tabular}{|c|c|c|c|c|c|c|c|c|c|c|}
\hline No & Species & Transect & Density & $\begin{array}{l}\text { Basal } \\
\text { area }\end{array}$ & Frequency & $\begin{array}{l}\text { Relative } \\
\text { Density }\end{array}$ & $\begin{array}{l}\text { Relative } \\
\text { dominance }\end{array}$ & $\begin{array}{l}\text { Relative } \\
\text { frequency }\end{array}$ & $\begin{array}{l}\text { Importance } \\
\text { Value }\end{array}$ & Rank \\
\hline \multirow{8}{*}{ I } & \multirow{8}{*}{$\begin{array}{l}\text { Rhizophora } \\
\text { apiculata }\end{array}$} & T-I & 197.9 & 0.6843 & 80.0 & 73.5 & 47.0 & 57.1 & 177.6 & 1 \\
\hline & & $\mathrm{T}-2$ & 162.4 & 0.5174 & 66.7 & 46.4 & 45.7 & 40.0 & 132.2 & I \\
\hline & & $\mathrm{T}-3$ & 168.3 & $0.57 \mid 4$ & 93.3 & 69.0 & 76.8 & 53.8 & 199.6 & I \\
\hline & & $\mathrm{T}-4$ & 133.7 & 1.1119 & 93.3 & 63.5 & 74.5 & 51.9 & 189.9 & I \\
\hline & & $\mathrm{T}-5$ & 113.6 & 0.3990 & 46.7 & 33.3 & 36.4 & 25.9 & 95.7 & I \\
\hline & & $\mathrm{T}-6$ & 112.1 & 0.3039 & 40.0 & 36.1 & 29.0 & 28.6 & 93.7 & 2 \\
\hline & & Total & 888.0 & 3.5879 & 1259.7 & 321.8 & 309.4 & 257.3 & 888.7 & \\
\hline & & Mean & 148 & 0.60 & 209.95 & 53.6 & 51.57 & 42.88 & 148.12 & \\
\hline \multirow{4}{*}{2} & \multirow{4}{*}{$\begin{array}{l}\text { Rhizophora } \\
\text { mucronata }\end{array}$} & $\mathrm{T}-\mathrm{I}$ & 11.0 & 0.0953 & 13.3 & 4.1 & 6.5 & 9.5 & 20.2 & 3 \\
\hline & & $\mathrm{T}-5$ & 26.2 & 0.0740 & 20.0 & 7.7 & 6.8 & II.I & 25.6 & 6 \\
\hline & & Total & 37.2 & 0.1693 & 33.3 & 11.8 & 13.3 & 20.6 & 45.8 & \\
\hline & & Mean & 18.6 & 0.08 & 16.65 & 5.9 & 6.65 & 10.3 & 22.9 & \\
\hline \multirow{8}{*}{3} & \multirow{8}{*}{$\begin{array}{l}\text { Bruguiera } \\
\text { gymnorhiza }\end{array}$} & T-I & 5.5 & 0.0108 & 6.7 & 2.0 & 0.7 & 4.8 & 7.5 & 7 \\
\hline & & $\mathrm{T}-2$ & 37.5 & 0.1117 & 13.3 & 10.7 & 9.9 & 8.0 & 28.6 & 4 \\
\hline & & $\mathrm{T}-3$ & 12.6 & 0.0218 & 20.0 & 5.2 & 2.9 & 11.5 & 19.6 & 3 \\
\hline & & $\mathrm{T}-4$ & 40.5 & 0.1374 & 33.3 & 19.2 & 9.2 & 18.5 & 47.0 & 2 \\
\hline & & $\mathrm{T}-5$ & 61.2 & 0.1948 & 26.7 & 17.9 & 17.8 & 14.8 & 50.6 & 2 \\
\hline & & $\mathrm{T}-6$ & 25.9 & 0.0670 & 13.3 & 8.3 & 6.4 & 9.5 & 24.2 & 4 \\
\hline & & Total & 183.2 & 0.5237 & 113.3 & 63.3 & 46.9 & 67.1 & 177.5 & \\
\hline & & Mean & 30.53 & 0.09 & 18.88 & 10.55 & 7.82 & II.I 8 & 29.58 & \\
\hline \multirow{6}{*}{4} & \multirow{6}{*}{$\begin{array}{l}\text { Bruguiera } \\
\text { sexangular }\end{array}$} & T-I & 5.5 & 0.0108 & 6.7 & 2.0 & 0.7 & 4.8 & 7.5 & 7 \\
\hline & & $\mathrm{T}-2$ & 56.2 & 0.2217 & 33.3 & 16.1 & 19.6 & 20.0 & 55.7 & 2 \\
\hline & & $\mathrm{T}-3$ & 42.1 & 0.0830 & 40.0 & 17.2 & 11.2 & 23.1 & 51.5 & 2 \\
\hline & & $\mathrm{T}-4$ & 8.1 & 0.0148 & 13.3 & 3.8 & 1.0 & 7.4 & 12.2 & 5 \\
\hline & & Total & 111.9 & 0.3303 & 93.3 & 39.1 & 32.5 & 55.3 & 126.9 & \\
\hline & & Mean & 27.96 & 0.08 & 23.33 & 9.78 & 8.13 & 13.83 & 31.73 & \\
\hline \multirow{5}{*}{5} & \multirow{5}{*}{$\begin{array}{l}\text { Bruguiera } \\
\text { cylindrica }\end{array}$} & $\mathrm{T}-\mathrm{I}$ & 22.0 & 0.0401 & 6.7 & 8.2 & 2.8 & 4.8 & 15.7 & 5 \\
\hline & & $\mathrm{T}-2$ & 6.2 & 0.0124 & 6.7 & 1.8 & I.I & 4.0 & 6.9 & 7 \\
\hline & & $\mathrm{T}-6$ & 8.6 & 0.0242 & 6.7 & 2.8 & 2.3 & 4.8 & 9.9 & 5 \\
\hline & & Total & 36.8 & 0.0767 & 20.1 & 12.8 & 6.2 & 13.6 & 32.5 & \\
\hline & & Mean & 12.27 & 0.03 & 6.7 & 4.27 & 2.07 & 4.53 & 10.83 & \\
\hline
\end{tabular}


Table continued...

\begin{tabular}{|c|c|c|c|c|c|c|c|c|c|c|}
\hline No & Species & Transect & Density & $\begin{array}{l}\text { Basal } \\
\text { area }\end{array}$ & Frequency & $\begin{array}{l}\text { Relative } \\
\text { Density }\end{array}$ & $\begin{array}{l}\text { Relative } \\
\text { dominance }\end{array}$ & $\begin{array}{l}\text { Relative } \\
\text { frequency }\end{array}$ & $\begin{array}{l}\text { Importance } \\
\text { Value }\end{array}$ & Rank \\
\hline \multirow{7}{*}{6} & \multirow{7}{*}{$\begin{array}{l}\text { Ceriops } \\
\text { tagal }\end{array}$} & T-I & 16.5 & 0.0247 & 13.3 & 6.1 & 1.7 & 9.5 & 17.3 & 4 \\
\hline & & $\mathrm{T}-2$ & 56.2 & 0.0991 & 33.3 & 16.1 & 8.8 & 20.0 & 44.8 & 3 \\
\hline & & $\mathrm{T}-4$ & 16.2 & 0.0296 & 20.0 & 7.7 & 2.0 & 11.1 & 20.8 & 3 \\
\hline & & $\mathrm{T}-5$ & 52.5 & 0.1145 & 26.7 & 15.4 & 10.5 & 14.8 & 40.7 & 4 \\
\hline & & $\mathrm{T}-6$ & 112.1 & 0.2488 & 53.3 & 36.1 & 23.7 & 38.1 & 97.9 & 1 \\
\hline & & Total & 253.5 & 0.5167 & 146.6 & 81.4 & 46.7 & 93.5 & 221.5 & \\
\hline & & Mean & 50.7 & 0.10 & 29.32 & 16.28 & 9.34 & 18.7 & 44.3 & \\
\hline \multirow{5}{*}{7} & \multirow{5}{*}{$\begin{array}{l}\text { Ceriop } \\
\text { sdecandra }\end{array}$} & $\mathrm{T}-2$ & 12.5 & 0.0201 & 6.7 & 3.6 & 1.8 & 4.0 & 9.4 & 6 \\
\hline & & T-5 & 17.5 & $0.028 I$ & 13.3 & 5.1 & 2.6 & 7.4 & 15.1 & 7 \\
\hline & & $\mathrm{T}-6$ & 8.6 & 0.0108 & 6.7 & 2.8 & 1.0 & 4.8 & 8.6 & 6 \\
\hline & & Total & 38.6 & 0.059 & 26.7 & II.5 & 5.4 & 16.2 & 33.1 & \\
\hline & & Mean & 12.87 & 0.02 & 8.9 & 3.83 & 1.8 & 5.4 & 11.03 & \\
\hline \multirow{3}{*}{8} & \multirow{3}{*}{$\begin{array}{l}\text { Avicennia } \\
\text { marina }\end{array}$} & TI & 5.5 & .0621 & 6.7 & 2.0 & 4.3 & 4.8 & II.I & 6 \\
\hline & & Total & 5.5 & .0621 & 6.7 & 2.0 & 4.3 & 4.8 & II.I & \\
\hline & & Mean & 5.5 & .0621 & 6.7 & 2.0 & 4.3 & 4.8 & I I.I & \\
\hline \multirow{3}{*}{9} & \multirow{3}{*}{$\begin{array}{l}\text { Avicennia } \\
\text { officinalis }\end{array}$} & T-I & 5.5 & 0.5284 & 6.7 & 2.0 & 36.3 & 4.8 & 43.1 & 2 \\
\hline & & Total & 5.5 & 0.5284 & 6.7 & 2.0 & 36.3 & 4.8 & 43.1 & \\
\hline & & Mean & 5.5 & 0.5284 & 6.7 & 2.0 & 36.3 & 4.8 & 43.1 & \\
\hline \multirow{3}{*}{10} & \multirow{3}{*}{$\begin{array}{l}\text { Avicennia } \\
\text { alba }\end{array}$} & $\mathrm{T}-4$ & 4.1 & 0.1831 & 6.7 & 1.9 & 12.3 & 3.7 & 17.9 & 4 \\
\hline & & Total & 4.1 & $0 .|83|$ & 6.7 & 1.9 & 12.3 & 3.7 & 17.9 & \\
\hline & & Mean & 4.1 & 0.1831 & 6.7 & 1.9 & 12.3 & 3.7 & 17.9 & \\
\hline \multirow{5}{*}{ II } & \multirow{5}{*}{$\begin{array}{l}\text { Xylocarpus } \\
\text { granatum }\end{array}$} & $\mathrm{T}-2$ & 18.7 & 0.1493 & 6.7 & 5.4 & 13.2 & 4.0 & 22.5 & 5 \\
\hline & & $\mathrm{T}-3$ & 12.6 & 0.0355 & 6.7 & 5.2 & 4.8 & 3.8 & 13.8 & 4 \\
\hline & & $\mathrm{T}-5$ & 26.2 & 0.0918 & 20.0 & 7.7 & 8.4 & II.I & 27.2 & 5 \\
\hline & & Total & 57.5 & 0.2766 & 33.4 & 18.3 & 26.4 & 18.9 & 63.5 & \\
\hline & & Mean & 19.17 & 0.09 & 11.13 & 6.1 & 8.8 & 6.3 & 21.17 & \\
\hline \multirow{3}{*}{12} & \multirow{3}{*}{$\begin{array}{l}\text { Heritiera } \\
\text { formes }\end{array}$} & $\mathrm{T}-3$ & 4.2 & 0.0053 & 6.7 & 1.7 & 0.7 & 3.8 & 6.3 & 6 \\
\hline & & Total & 4.2 & 0.0053 & 6.7 & 1.7 & 0.7 & 3.8 & 6.3 & \\
\hline & & Mean & 4.2 & 0.0053 & 6.7 & 1.7 & 0.7 & 3.8 & 6.3 & \\
\hline \multirow{3}{*}{13} & \multirow{3}{*}{$\begin{array}{l}\text { Nypa } \\
\text { fruticans }\end{array}$} & $\mathrm{T}-3$ & 4.2 & 0.0268 & 6.7 & 1.7 & 3.6 & 3.8 & 9.2 & 5 \\
\hline & & Total & 4.2 & 0.0268 & 6.7 & 1.7 & 3.6 & 3.8 & 9.2 & \\
\hline & & Mean & 4.2 & 0.0268 & 6.7 & 1.7 & 3.6 & 3.8 & 9.2 & \\
\hline \multirow{3}{*}{14} & \multirow{3}{*}{$\begin{array}{l}\text { Sonneratia } \\
\text { alba }\end{array}$} & $\mathrm{T}-4$ & 4.1 & 0.0070 & 6.7 & 1.9 & 0.5 & 3.7 & 6.1 & 7 \\
\hline & & Total & 4.1 & 0.0070 & 6.7 & 1.9 & 0.5 & 3.7 & 6.1 & \\
\hline & & Mean & 4.1 & 0.0070 & 6.7 & 1.9 & 0.5 & 3.7 & 6.1 & \\
\hline \multirow{4}{*}{15} & \multirow{4}{*}{$\begin{array}{l}\text { Lumnizera } \\
\text { littorea }\end{array}$} & T-5 & 43.7 & 0.1928 & 26.7 & 12.8 & 17.6 & 14.8 & 45.2 & 3 \\
\hline & & $\mathrm{T}-6$ & 43.1 & 0.3939 & 20.0 & 13.9 & 37.6 & 14.3 & 65.7 & 3 \\
\hline & & Total & 86.8 & 0.5867 & 46.7 & 26.7 & 55.2 & 29.1 & 110.9 & \\
\hline & & Mean & 43.4 & 0.29 & 23.35 & 13.35 & 27.6 & 14.55 & 55.45 & \\
\hline
\end{tabular}

Table 6 Forest parameter of different mangrove species at Magyi and Utoe creek, in Shwe-Thaung-Yan coastal Area

\begin{tabular}{|c|c|c|c|c|c|c|}
\hline Sr. No. & Species & $\begin{array}{l}\text { Mean Basal } \\
\text { area }\end{array}$ & $\begin{array}{l}\text { Mean } \\
\text { Relative } \\
\text { Density }\end{array}$ & $\begin{array}{l}\text { Mean Relative } \\
\text { dominance }\end{array}$ & $\begin{array}{l}\text { Mean Relative } \\
\text { frequency }\end{array}$ & $\begin{array}{l}\text { Mean Importance } \\
\text { Value }\end{array}$ \\
\hline I & Rhizophora apiculata & 0.60 & 53.50 & 51.60 & 42.90 & 148.12 \\
\hline 2 & Rhizophora mucronata & 0.08 & 5.90 & 6.50 & 10.30 & 22.90 \\
\hline 3 & Bruguiera gymnorhiza & 0.09 & 10.55 & 7.82 & 11.18 & 29.58 \\
\hline 4 & Bruguiera sexangular & 0.08 & 9.78 & 8.13 & 13.83 & 31.72 \\
\hline 5 & Bruguiera cylindrica & 0.03 & 4.27 & 2.07 & 4.53 & 10.83 \\
\hline
\end{tabular}

Citation: Soe-Win, Tin-Zar-Ni-Win.Vegetative structure and zonal distribution of true mangroves in Shwe-Thaung-Yan coastal areas, Myanmar.J Aquac Mar Biol. 2021;I0(I):33-39. DOI: 10.15406/jamb.2021.10.00305 
Table continued.

\begin{tabular}{lllllll}
\hline Sr. No. & Species & $\begin{array}{l}\text { Mean Basal } \\
\text { area }\end{array}$ & $\begin{array}{l}\text { Mean } \\
\text { Relative } \\
\text { Density }\end{array}$ & $\begin{array}{l}\text { Mean Relative } \\
\text { dominance }\end{array}$ & $\begin{array}{l}\text { Mean Relative } \\
\text { frequency }\end{array}$ & $\begin{array}{l}\text { Mean Importance } \\
\text { Value }\end{array}$ \\
\hline 6 & Ceriops tagal & 0.10 & 16.28 & 9.34 & 18.70 & 44.30 \\
7 & Ceriops decandra & 0.02 & 3.83 & 1.80 & 5.40 & 11.03 \\
8 & Avicennia marina & 0.06 & 2.00 & 4.30 & 4.80 & 11.10 \\
9 & Avicennia officinalis & 0.53 & 2.00 & 36.30 & 4.80 & 43.10 \\
10 & Avicennia alba & 0.18 & 1.90 & 12.30 & 3.70 & 17.90 \\
11 & Xylocarpus granatum & 0.09 & 6.10 & 8.80 & 6.30 & 21.17 \\
12 & Heritiera formes & 0.01 & 1.70 & 0.70 & 3.80 & 6.30 \\
13 & Nypa fruticans & 0.03 & 1.70 & 3.60 & 3.80 & 9.20 \\
14 & Sonneratia alba & 0.01 & 1.90 & 0.50 & 3.70 & 6.10 \\
15 & Lumnizera littorea & 0.29 & 13.35 & 27.60 & 14.55 & 55.45 \\
\hline
\end{tabular}

Table 7 The environmental parameter ranges in the Magyi and Utto creeks, Shwe-Thaung-Yan coastal Area

\begin{tabular}{llllllll}
\hline Sr No. & Environmental parameters & T .I & T .2 & T.3 & T.4 & T.5 & T.6 \\
\hline I & Water salinity(\%) & 35.0 & 32.0 & 32.0 & 35.2 & 35.0 & 35.8 \\
2 & Water temperature ( C) & 35.1 & 30.0 & 32.0 & 33.0 & 32.5 & 33.4 \\
3 & Soil Salinity(\%) & 55.0 & 30.0 & 31.3 & 48.0 & 48.0 & 42.0 \\
4 & Soil temperature & 33.4 & 29.5 & 32.0 & 34.2 & 31.0 & 32.6 \\
5 & Soil pH & 6.2 & 5.8 & 5.9 & 6.0 & 6.4 & 6.2 \\
\hline
\end{tabular}

\section{Acknowledgements}

We are greatly indebted to Dr San Tha Tun, Professor and Head, Department of Marine Science, Mawlamyine University, for his encouragement throughout the study period. We would like to acknowledge to Dr Htay Aung (Professor Retire) for reading this manuscript. We sincerely thank the local villagers for their helpful assistance in field works. The first author, Soe Win, would like to thank he beloved family for their physical, moral and financial supports throughout this study.

\section{Funding}

None.

\section{Conflicts of interest}

The author declares that there is no conflicts of interest.

\section{References}

1. Dahdouh-Guebas F, Koedan N Empirical estimate of the reliability of the uses of Point Center Quarter Method (PCQR), Biocomplexity Research Team, Laboratory of General Botany and Nature Management. Forest Ecology and Management. 2006;(1-3):1-18.

2. San ThaTun, Tint Swe, Tint Tun. The preliminary study on the mangrove of Lampi Island and adjacent areas. $18 \mathrm{p}$.

3. Malar. Morphology and ecology of mangroves and associate in Myeik Coastal Zone, unpublished PhD Dissertation, Department of Marine Science, Universitiey of Yangon, Myanmar.2009; 167 p.

4. Myat Myat Moe. Botanical study of Importance of Mangrove Ecosystem for conservation and Management purpose. Research paper, Department of Botany, Myeik University, 2009; 12 p.

5. San ThaTun, Win Hteik, Kyaw Thura. Survey of mangroves in Auckland
Bay and Adjacent Areas, Kyun-Su and Boke-Pyi Townships, Tanintharyi Region. 2014; 28 p.

6. Pyae Sone Aung. Mangrove of Shwe Bay Area, Myeik, Tanintharyi Region. Unpublished MSc Thesis,Marine Science Department, Myeik University, Myanmar 2015; 86 p.

7. Nan Htwe Htwe Maung. Zonation patterns of mangrove in Magyi Tidal Creek, Unpublished MSc Thesis, Marine Science Department, Pathein, Myanmar, 2011; 40 p.

8. Aung Myint, Kyaw Soe. Mangrove communities of the Irrawaddy and Salween Deltas of Burma. Wallaceana A global Newsletter for tropical Ecology 1985; 40: 3-5 p

9. Ohn U. 1992. Mangroves forest products and utilization of AyeyarwaddyDelta .Feasibility study on Mangrove reforestation. FAO /FO: Mya/ 90/003. Yangon No.4,1992;18 p

10. Htoo Lwin Aung. Study on the species composition, zonation pattern and some successional features of mangrove community along magyi coastal areas, ShweThaung Yan Sub - Township. 2016.

11. Dahdouh-Guebas F, Koedan N. A synthesis of existent and potential mangrove vegetation structure dynamics from Kenyan Sri Lankan and Mauritanian. 2002;487-511 p.

12. Kario JG, Dahdouh-Guebas F, Gwada PO, et al. Regeneration status of mangrove forests in Mida Creek, Kenya. 2002;562-586.

13. Duke NC. Australias Mangroves. The authoritative guide to Australia mangrove plants. University of Queensland, Brisbane, 2006; 200 p.

14. Myra DS, Maria LS and Annielyn DT, et al., The effect of environmental factors on the growth of mangrove seedlings in Kauswagan, Lanaodel Norte, Mindanao, Philippines.Advances in Agriculture \&BotanicsInternation Journal of Biofiux Society. 2015; 6 p.

15. Kathiresan K, Bingham BL. Biology of Mangroves and Mangrove Ecosystems, Advances in marine biology. 2001;40: 81-251. 